\title{
COVID-19 among patients with Behçet syndrome in the USA
}

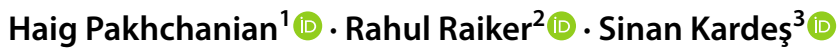

Received: 18 August 2021 / Revised: 20 September 2021 / Accepted: 21 September 2021 / Published online: 25 September 2021

(C) International League of Associations for Rheumatology (ILAR) 2021

Key Points

- Patients with Behçet syndrome were not at an increased risk of worse COVID-19 outcomes compared to the general population in the USA.

\section{Dear Editor,}

Behçet syndrome is a chronic multisystem condition that is characterized by relapsing-remitting periods of a diverse spectrum of manifestations [1]. Although it is more common along the ancient Silk Road [1], it is a rare syndrome with a prevalence of 5.2 per 100,000 in the USA [2]. During the COVID-19 pandemic, concerns have been raised about whether patients with Behçet syndrome are at an increased risk of worse COVID-19 outcomes. To address these concerns, small case series of 4 and 10 Behçet syndrome patients with COVID-19 have been reported from Spain [3] and Turkey [4], respectively. Moreover, 14 Behçet syndrome patients with COVID-19 have been reported from Italy [5]. In addition, in a digital conference, experts from ten countries reported the hospitalization, ICU admission, and case fatality rate of Behçet syndrome patients with COVID-19 in their hospitals or countries [6]. There is a need for a systematic study, which includes large-scale nationwide data, to increase our understanding regarding the risk of worse COVID-19 outcomes in Behçet syndrome.

Haig Pakhchanian

haig@gwmail.gwu.edu

$\triangle$ Rahul Raiker

rsraiker@gmail.com

Sinan Kardeş

snnkrds@gmail.com; sinan.kardes@istanbul.edu.tr

1 George Washington University School of Medicine \& Health Sciences, Washington, DC, USA

2 West Virginia University School of Medicine, Morgantown, WV, USA

3 Istanbul University Istanbul Faculty of Medicine, Capa-Fatih, 34093 Istanbul, Turkey
In this retrospective comparative cohort study, we used the TriNetX database, which contains de-identified electronic health records of more than 73 million persons from 53 US healthcare organizations. We included all adults (aged $\geq 18$ years) with a pre-existing diagnosis of Behçet syndrome (M35.2) who were diagnosed with COVID-19 between January 20, 2020 (first confirmed COVID-19 case in the USA) and June 18, 2021. The comparative cohort included adult COVID-19 patients without Behçet syndrome. The primary outcomes of interest were hospitalization and severe COVID-19, which was defined as a composite outcome of mortality, intensive care unit admission, mechanical ventilation, acute kidney injury, acute respiratory distress syndrome, ischemic stroke, venous thromboembolism, and/or sepsis, within 45 days of COVID-19 diagnosis. We used 1:1 propensity score matching and calculated risk ratios and $95 \%$ confidence interval (CI). The database and statistical analyses that we used have been detailed previously $[7,8]$.

The cohort consisted of 141 Behçet syndrome with COVID-19 and 864,533 COVID-19 patients without Behçet syndrome. Patients with Behçet syndrome were of a similar age and more likely to be female (consistent with the general epidemiology of Behçet syndrome in the USA $[2,9]$ ) compared to the comparative cohort. A majority of Behçet syndrome patients (58\%) were prescribed glucocorticoids, with $18 \%$ colchicine, and $12 \%$ azathioprine in the preceding year of COVID-19 diagnosis. The hospitalization rate was $18 \%$ in the Behçet syndrome cohort. The risk of hospitalization and severe COVID-19 did not significantly differ between Behçet syndrome with COVID-19 and the comparative cohort both in unadjusted and propensity score matching analyses (Table 1).

In conclusion, we found that patients with Behçet syndrome were not at an increased risk of worse COVID-19 outcomes compared to the general population in the USA.

Although this was a large national study, it has limitations including possible errors in coding/data entry, which are inherent limitations of studies using electronic health records. In addition, most of the patients with Behçet 
Table 1 Baseline characteristics, comorbidities, and COVID-19 outcomes in cohorts before and after propensity matching*

\begin{tabular}{|c|c|c|c|c|c|c|}
\hline \multirow{2}{*}{$\begin{array}{l}\text { Baseline charac- } \\
\text { teristic }\end{array}$} & \multicolumn{3}{|c|}{ Before propensity matching } & \multicolumn{3}{|c|}{ After propensity matching } \\
\hline & $\begin{array}{l}\text { Behçet with } \\
\text { COVID-19 } \\
(n=141)\end{array}$ & $\begin{array}{l}\text { Non-Behçet } \\
\text { with COVID-19 } \\
(n=864,854)\end{array}$ & $\begin{array}{l}\text { Standardized dif- } \\
\text { ference }\end{array}$ & $\begin{array}{l}\text { Behçet with } \\
\text { COVID-19 } \\
(n=141)\end{array}$ & $\begin{array}{l}\text { Non-Behçet } \\
\text { with COVID-19 } \\
(n=141)\end{array}$ & $\begin{array}{l}\text { Standardized dif- } \\
\text { ference }\end{array}$ \\
\hline Age, years & $46.8 \pm 15.3$ & $47.6 \pm 18.5$ & 0.0459 & $46.8 \pm 15.3$ & $48.5 \pm 16.3$ & 0.1044 \\
\hline Female sex $\ddagger$ & $104(73.759 \%)$ & $474,189(54.829 \%)$ & 0.403 & $104(73.759 \%)$ & $104(73.759 \%)$ & $<0.0001$ \\
\hline \multicolumn{7}{|l|}{ Race } \\
\hline White & $93(65.957 \%)$ & $500,387(57.858 \%)$ & 0.1674 & $93(65.957 \%)$ & $97(68.794 \%)$ & 0.0605 \\
\hline Black & $16(11.348 \%)$ & $142,730(16.503 \%)$ & 0.1493 & $16(11.348 \%)$ & $12(8.511 \%)$ & 0.095 \\
\hline Asian & $<11 \dagger(\mathrm{NA} \%)$ & $18,721(2.165 \%)$ & 0.2362 & $<11 \dagger(\mathrm{NA} \%)$ & $<11 \dagger(\mathrm{NA} \%)$ & $<0.0001$ \\
\hline BMI, $\mathrm{kg} / \mathrm{m}^{2}$ & $28.7 \pm 6.43$ & $30.6 \pm 7.51$ & 0.2673 & $28.7 \pm 6.43$ & $32.2 \pm 7.99$ & 0.473 \\
\hline Hypertension & $57(40.426 \%)$ & $214,607(24.814 \%)$ & 0.3377 & $57(40.426 \%)$ & $59(41.844 \%)$ & 0.0288 \\
\hline $\begin{array}{c}\text { Chronic lower } \\
\text { lung disease }\end{array}$ & $39(27.66 \%)$ & $122,287(14.14 \%)$ & 0.3372 & $39(27.66 \%)$ & $42(29.787 \%)$ & 0.047 \\
\hline Diabetes mellitus & $25(17.73 \%)$ & $103,657(11.985 \%)$ & 0.1621 & $25(17.73 \%)$ & $25(17.73 \%)$ & $<0.0001$ \\
\hline $\begin{array}{l}\text { Ischemic heart } \\
\text { disease }\end{array}$ & $11(7.801 \%)$ & $63,510(7.343 \%)$ & 0.0173 & $11(7.801 \%)$ & $<11 \dagger$ & NA \\
\hline $\begin{array}{l}\text { Chronic kidney } \\
\text { disease }\end{array}$ & $15(10.638 \%)$ & $44,681(5.166 \%)$ & 0.2039 & $15(10.638 \%)$ & $<11 \dagger$ & NA \\
\hline Heart failure & $<11 \dagger$ & $36,016(4.164 \%)$ & NA & $<11 \dagger$ & $<11 \dagger$ & NA \\
\hline $\begin{array}{l}\text { Cerebrovascular } \\
\text { disease }\end{array}$ & $13(9.22 \%)$ & $38,242(4.422 \%)$ & 0.1912 & $13(9.22 \%)$ & $<11 \dagger$ & NA \\
\hline $\begin{array}{l}\text { Nicotine depend- } \\
\text { ence }\end{array}$ & $21(14.894 \%)$ & $60,335(6.976 \%)$ & 0.2558 & $21(14.894 \%)$ & $24(17.021 \%)$ & 0.0581 \\
\hline $\begin{array}{l}\text { Alcohol-related } \\
\text { disorders }\end{array}$ & $<11 \dagger$ & $19,827(2.293 \%)$ & NA & $<11 \dagger$ & $<11 \dagger$ & NA \\
\hline Neoplasms & $48(34.043 \%)$ & $151,908(17.565 \%)$ & 0.3835 & $48(34.043 \%)$ & $38(26.95 \%)$ & 0.1545 \\
\hline $\begin{array}{l}\text { Interstitial lung } \\
\text { disease }\end{array}$ & $<11 \dagger$ & $3,213(0.372 \%)$ & NA & $<11 \dagger$ & $<11 \dagger$ & NA \\
\hline \multicolumn{7}{|c|}{ COVID-19 outcomes } \\
\hline \multirow[t]{2}{*}{ Outcome } & \multicolumn{3}{|c|}{ Before propensity matching } & \multicolumn{3}{|c|}{ After propensity matching } \\
\hline & $\begin{array}{l}\text { Behçet with } \\
\text { COVID-19 } \\
(n=141)\end{array}$ & $\begin{array}{l}\text { Non-Behçet with } \\
\text { COVID-19 } \\
(n=864,854)\end{array}$ & $\begin{array}{l}\text { Risk ratio }(95 \% \\
\mathrm{CI}) / p \text { value }\end{array}$ & $\begin{array}{l}\text { Behçet with } \\
\text { COVID-19 } \\
(n=141)\end{array}$ & $\begin{array}{l}\text { Non-Behçet with } \\
\text { COVID-19 } \\
(n=141)\end{array}$ & $\begin{array}{l}\text { Risk ratio }(95 \% \\
\mathrm{CI}) / p \text { value }\end{array}$ \\
\hline Hospitalization & $26(18.440 \%)$ & $132,129(15.278 \%)$ & $\begin{array}{l}1.207 \\
\quad(0.853,1.708) \\
p: 0.2967\end{array}$ & $26(18.440 \%)$ & $19(13.475 \%)$ & $\begin{array}{l}1.368(0.795,2.357) \\
p: 0.2550\end{array}$ \\
\hline $\begin{array}{l}\text { Severe COVID- } \\
19 \S\end{array}$ & $13(9.220 \%)$ & $75,483(8.728 \%)$ & $\begin{array}{l}1.056 \\
\quad(0.629,1.773) \\
p: 0.8360\end{array}$ & $13(9.220 \%)$ & $12(8.511 \%)$ & $\begin{array}{l}1.083(0.512,2.291) \\
p: 0.8341\end{array}$ \\
\hline
\end{tabular}

*Data are mean \pm standard deviation or number (percentage). Age, sex, race, body mass index (BMI), and comorbidities (hypertension, chronic lower lung disease, diabetes mellitus, ischemic heart disease, chronic kidney disease, heart failure, cerebrovascular disease, nicotine dependence, alcohol-related disorders, neoplasms, and interstitial lung disease, which were defined through International Classification of Diseases codes) were included as covariates in propensity score matching

${ }^{\dagger}$ TriNetX obfuscates the number if the event count is less than 11 for privacy reasons

${ }^{\ddagger}$ Sex data were unknown for 4 (2.8\%) Behçet patients. Race data were unknown for 29 (20.6\%) Behçet patients and the other races (e.g., Native Hawaiian/Pacific Islander) were obfuscated due to less than 11. Percentage data are among all patients in each cohort (not on available data)

${ }^{\S}$ Composite outcome of mortality, intensive care unit admission, mechanical ventilation, acute kidney injury, acute respiratory distress syndrome, ischemic stroke, venous thromboembolism, and/or sepsis

syndrome were women, and their clinical characteristics could not be evaluated as the database did not provide this information. Furthermore, because Behçet syndrome is less severe in the USA than in endemic areas [1,9], US results may not be generalizable to regions where Behçet syndrome is endemic and more severe. 
Author contribution HP, RR, and SK designed the study. HP and RR carried out statistical analyses. All authors contributed to interpretation of data. SK drafted the manuscript. HP, RR, and SK critically revised the article.

\section{Declarations}

Financial disclosures SK has received congress travel, accommodation, and participation fee support (12th Anatolian Rheumatology Days) from AbbVie (payments were made to congress) (outside of submitted manuscript). Both other authors declare no conflict of interests.

\section{References}

1. Yazici H, Seyahi E, Hatemi G, Yazici Y (2018) Behçet syndrome: a contemporary view. Nat Rev Rheumatol 14:107-119. https://doi. org/10.1038/nrrheum.2017.208

2. Calamia KT, Wilson FC, Icen M, Crowson CS, Gabriel SE, Kremers HM (2009) Epidemiology and clinical characteristics of Behçet's disease in the US: a population-based study. Arthritis Rheum 61:600-604. https://doi.org/10.1002/art.24423

3. Espinosa G, Araujo O, Amaro S, Bodro M, Moreno PJ, Moreno R, Ugarte A, Cervera R (2021) COVID-19 and Behçet's disease: clinical case series. Ann Rheum Dis 80:e41. https://doi.org/10. 1136/annrheumdis-2020-217778

4. Yurttaş B, Oztas M, Tunc A, Balkan III, Tabak OF, Hamuryudan V, Seyahi E (2020) Characteristics and outcomes of Behçet's syndrome patients with coronavirus disease 2019: a case series of
10 patients. Intern Emerg Med 15:1567-1571. https://doi.org/10. 1007/s11739-020-02427-8

5. Mattioli I, Bettiol A, Silvestri E, et al (2021) Prevalence and clinical course of SARS-CoV-2 infection in patients with Behçet's syndrome. Clin Exp Rheumatol. Epub ahead of print.

6. Zouboulis CC, van Laar JAM, Schirmer M, Emmi G, Fortune F, Gül A, Kirino Y, Lee ES, Sfikakis PP, Shahram F, Wallace GR (2021) Adamantiades-Behçet's disease (Behçet's disease) and COVID-19. J Eur Acad Dermatol Venereol 35:e541-e543. https://doi.org/10.1111/jdv.17325

7. Singh S, Bilal M, Pakhchanian H, Raiker R, Kochhar GS, Thompson CC (2020) Impact of obesity on outcomes of patients with coronavirus disease 2019 in the United States: a multicenter electronic health records network study. Gastroenterology 159:22212225.e6. https://doi.org/10.1053/j.gastro.2020.08.028

8. Raiker R, DeYoung C, Pakhchanian H, Ahmed S, Kavadichanda C, Gupta L, Kardeş S (2021) Outcomes of COVID-19 in patients with rheumatoid arthritis: a multicenter research network study in the United States. Semin Arthritis Rheum 51:1057-1066. https:// doi.org/10.1016/j.semarthrit.2021.08.010

9. Sibley C, Yazici Y, Tascilar K, Khan N, Bata Y, Yazici H, Goldbach-Mansky R, Hatemi G (2014) Behçet syndrome manifestations and activity in the United States versus Turkey - a crosssectional cohort comparison. J Rheumatol 41:1379-1384. https:// doi.org/10.3899/jrheum.131227

Publisher's note Springer Nature remains neutral with regard to jurisdictional claims in published maps and institutional affiliations. 